\title{
Ebelik Öğrencilerinin Doğum Simülasyon Eğitimi Deneyimleri
}

\author{
Fadime Bayrı Bingölø, Meltem Demirgöz Bal๑, Ayşe Karakoç®, Begüm Aslan®
}

Marmara Üniversitesi, Ebelik, Istanbul, Türkiye

Fadime Bayrı Bingöl, Dr. Öğr. Üyesi Meltem Demirgöz Bal, Doç. Dr. Ayşe Karakoç, Doç. Dr. Begüm Aslan, Arş. Gör.
İletişim:

Dr. Öğr. Üyesi Fadime Bayrı Bingöl Marmara Üniversitesi, Ebelik, İstanbul, Türkiye Tel: +902163302070

E-Posta: fadimebayri@gmail.com
Gönderilme Tarihi : 09 Temmuz 2019

Revizyon Tarihi : : 03 Eylül 2019

Kabul Tarihi : : 03 Kasım 2019

\section{ÖZET}

Amaç: Bu çalışma, ebelik bölümünde simülasyon eğitimi sonrasında öğrencilerin deneyimlerini değerlendirmek amacıyla yapılmıştır.

Hastalar ve Yöntem: Yarı yapılandırılmış bireysel görüşşmelere dayalı niteliksel tanımlayııı fenomenolojik bir araştırmadır. Marmara Üniversitesi Sağık Bilimleri Fakültesi Ebelik Bölümünde yapılmıştır. Doğum dersi alan 65 öğrenciye, 14 hafta boyunca verilen normal doğum simülasyon uygulamasının değerlendirmesi hedeflenerek, araştırma örneklemi yüz yüze bireysel derinlemesine görüşmeyi kabul eden 19 ebelik öğrencisidir.

Bulgular: Katılımının yaş ortalaması 20,94 $\pm 1,26$ (Min: 20, Maks: 25) ve hepsi bekardır. Yapılan görüşmelerden tematik içerik analizine dayanarak, öğrencilerin deneyimleri üç kategoride kümelenmiştir: simülasyon öncesi, simülasyon ve simülasyon çekinceleri. Bu kategorilerden çeşitli temalar ortaya çıkmıştır. Her bir kategorideki temalar yapısal, emotional-cognitive ve fiziksel olmak üzere gruplandırılmıştır.

Sonuç: Simülasyon eğitimi ebelik öğrencilerinin öğrenmesinde etkilidir ve pek çok avantajı vardır. Simülasyon eğitiminde öğrencilerin el becerilerinin geliştiği belirlenmiştir. Simülasyon eğitiminde öğrencilerin mesleki aidiyet duygularının güçlendiği belirlenmiştir. Simülasyon eğitiminde öğrencilerin özgüvenlerinin arttı̆ı̆ı belirlenmiştir. Simülatörün iyi ıkınması vb gerçeğe uygunluğu konusunda çekinceler vardır. Simülasyon eğitimi sonrasından öğrencilerimizden gelen geri bildirimlerin çoğunlukla pozitif yöndedir. Simülasyon ayrıca profesyonel ebe kimliğini alabilmelerinde destekleyici rol üstlenmektedir.

Anahtar sözcükler: Ebelik öğrencileri, simülasyon eğitimi, öğrenci deneyimleri, niteliksel araştırma.

\section{THE EFFECTS OF BIRTH SIMULATION EDUCATION/TRAINING IN MIDWIFERY STUDENTS}

\section{ABSTRACT}

Objectives: This study was conducted to evaluate the experiences of the students after simulation education in midwifery department.

Patients and Methods: It is a qualitative descriptive phenomenological study based on semi-structured interviews. It was conducted at Marmara University, Health Sciences Faculty, Midwifery Department. It is aimed to evaluate the birth simulation practice that was given for 14 weeks to 65 students who took the birth course. A total of 19 midwifery students who participated to do in-depth interviews were included in the study.

Results: The average age of the participants was $20.94 \pm 1.26$ years (Min: 20, Max: 25) and all of them were single. The experiences of the students were clustered into three categories by using thematic content analysis of the interviews: pre-simulation, simulation and limitations on the simulation. Various sub-themes were composed of these categories. Themes in every category were grouped as structural, emotional-cognitive and physical.

Conclusion: Simulation education is very effective on midwifery students' learning and has got a lot of advantages. It was determined that students' hand skills were improved by simulation education. In simulation education, it was determined that students' sense of professional belonging was strengthened. It was determined that students' selfconfidence increased in simulation education. Simulators are good but they lack real straining to conformity. The simulation education feedback from our students was mostly positive. Simulation education is also taking a supportive role for professional midwife identity/self-confidence.

Keywords: Student midwives, simulation education/training, student experience, qualitative research. 
E belikte simülasyon eğitimi; el becerilerinin geliştirilmesi, klinik uygulamalarda kaygılarının azalması, güvenli bir ortamda ve malpraktis riskinden uzak öğrenme gibi fırsatları sunmaktadır (1). Simülasyon eğitimi sağlık bakım alanında, güçlü ve kanıt temelli bir öğrenme metodudur $(2,3)$.

Türkiye, Birleşmiş Milletlere üye ülkeler arasında en yüksek sezaryen oranına sahip ülkedir (4). Normal doğum oranlarının yükseltilmesi ebeler olmadan mümkün değildir. Ülkemizde ebelik eğitiminde öğrenciler teorik olarak oldukça donanımlı olmalarına rağmen, uygulama becerisi kazanmada yetersiz kalma riski yaşanmaktadır. Ülkemiz sağlık sisteminde kadın doğum hekimlerinin eğitimine öncelik verildiğinden ebelik öğrencilerinin doğum sürecini yönetmeyi öğrenme şansı azalmaktadır. Ayrıca ebelik öğrencilerinin, öğretim üyelerinden destek ve danışmanlık alamadan doğrudan gebe üzerinde uygulama yapması, hasta güvenliği için ciddi bir risk oluşturmaktadır. Bu durum öğrencinin yaşadığı korku ve kaygılar nedeniyle, mesleki motivasyon ve iş doyumunu da olumsuz etkileyebilmektedir. Mesleki motivasyonu yüksek ve kendi alanında çalışan, özgüvenli ebelerin yetişmesinde simülasyon eğitimi fark yaratabilir. Araştırma bu bilgiler ışığında, ebelik bölümünde simülasyon eğitimi sonrasında öğrencilerin deneyimlerini değerlendirmek amacıyla yürütülmüştür.

\section{Gereç ve Yöntem}

Araştırma tipi

Araştırma niteliksel tanımlayıcı fenomenolojik bir araştırmadır.

\section{Araştırmanın etik yönü}

Bu çalışmanın yürütülebilmesi için kurum izni Marmara Üniversitesi Sağlık Bilimleri Fakültesi Dekanlığı (Tarih:15.02.2018, Sayı:80355971-020-E.1800051027) ve Marmara Üniversitesi Sağlık Bilimleri Enstitüsü Etik Kurulu'ndan (Tarih: 05.03.2018, Sayı:82) onay alınmıştır. Araştırma süresince Helsinki Deklarasyonunda belirtilen etik gereklilikler yerine getirilmiştir. Öğrencilere simülasyon eğitiminde görevli olmayan bir öğretim üyesi tarafından araştırmanın amacını ve prosedürünü açıklayan bilgi verilerek, araştırmaya davet edilmiştir. Öğrencilerin simülasyon eğitiminde görevli olmayan bir öğretim üyesi (FBB) tarafından araştırmaya davet edilmesinin nedeni doğrudan doğum dersini yürüten öğretim üyesinin davetindeki baskı unsurunu ortadan kaldırmak ve olası biası engellemek amacıyladır. Katıımcılar araştırmaya katıımın gönüllülük esasına dayalı olduğu ve herhangi bir açıklama yapmadan istedikleri zaman geri çekilebilecekleri konusunda bilgilendirilmişlerdir. Öğrencilere araştırmaya katılmayı ve verilerin kaydedilmesi için ses kayıt cihazı kullanılmasını kabul edip etmedikleri ile ilgili sözlü onamları alınmıştır.

\section{Simülasyon eğitimi}

Simülatör GAUMARD marka, Noelle-S554,100 modelidir. Marmara Üniversitesi, lisans ebelik 3. sınıf, doğum dersinde, 65 öğrenci ile 14 hafta boyunca birebir öğretim üyesi ile normal doğum simülasyon uygulaması yapılmıştır. Her öğrencinin en az ortalama 30 dakika süren sekiz farklı normalden sapma olmayan senaryoda doğum yönetmesi sağlanmıştır. Tüm senaryolarda öğrenciler yalnızca ebe rolü almaktadır. Senaryolardaki farklılıklar, gebenin primipar yada multipar olması, gebenin yaşı, doğum süresi, ağrı algısıdır. Simülasyon eğitimi öğrencilere; doğru vaginal muayene ile dilatasyon ve efasmanı değerlendirme, fetal başı değerlendirme, uygun manevralarla doğum yaptırma becerilerinin geliştirilmesi ve gebenin ağrıya verdiği tepkileri (simülatör doğumun ilerleyen aşamalarına göre, "yardım edin", "bebek geliyor", "dayanamıyorum", "nefes alamıyorum", "çok canım acıyor", "tükendim" vb sesli tepkiler de vermektedir) yönetme becerisi kazandırmaktadır.

\section{Örneklem}

Tüm öğrencilere normal doğum teorik bilgisi detaylarıyla anlatımıştır. Bu çalışmaya: gönüllü olarak katılmayı isteyen, daha önceki dönemlerde gebelik ve doğum derslerini başarıyla tamamlamış, daha önce simülasyon eğitimi almayan, daha önce canlı doğum yaptırmamış ve simülasyon eğitiminde en az sekiz senaryoyu birebir öğretim üyesinin eşliğinde tamamlamış öğrenciler alınmıştır. Simülasyon grubundaki sekiz senaryo sadece kadının bireysel (yaş, eğitim, parite vb.) değişkenleri içermektedir. Bu senaryoların hepsinde kadın normal doğum yapmaktadır. Araştırma için örneklem seçimine gidilmeyerek araştırmaya katılmayı kabul eden ve deneyimlerini paylaşmaya gönüllü toplam 21 öğrenci ile görüşme yapılmıştır. Araştırma süresince görüşülen 21 öğrenciden 2 öğrencinin sorulan sorulara yüzeysel ve kısa yanıtlar vermesi nedeniyle değerlendirme dışında tutulmuştur. On beşinci öğrenciden sonra, öğrencilerle yapılan tüm görüşmelerde, tüm söylemlerin birbirini tekrar ettiği görülmüştür. 21 öğrenciye kadar veri toplamaya devam edilmiş ancak yeni bir yanıt elde edilemediği görüldüğünde, araştırmanın veri doygunluğu açısından doyum noktası sağlandığı düşünülerek veri toplama tamamlanmıştır. Bu araştırma kuramsal örnekleme yöntemi kullanılarak; araştırma sorusunun yanıtı olabilecek kavram ve ifadeler tekrar etmeye başladığında (doyum noktası sağlandığında) veri toplama aşaması sonlandırılmıştır. 
Verilerin elde edilmesi

Veriler simülasyon eğitimini tamamlayan öğrencilerle, eğitimden hemen sonra yüz yüze bireysel derinlemesine görüşme ile elde edilmiştir. Görüşmeler mahremiyete özen gösterilerek, boş bir derslikte yapılmıştır. Görüşme sırasında ses kaydının yanı sıra ayrıntılı notlar alınmıştır. Araştırmacıların literatür incelemesi sonucunda oluşturduğu katılımcının yaşı ve ebelik mesleği tercih nedeninden sonra simülasyon eğitimi konusunda sorular sorulmuştur.

Bireysel görüşme sırasında sorulan sorular:

1. Simülasyon eğitimi sizin için nasıl bir deneyimdi?

2. Birebir öğretim üyesi eşliğinde simülasyon üzerinde doğum yönetimini deneyimlemek nasıldı?

3. Simülasyon maketinde doğumu yönetirken ebe olarak neler hissettiniz?

4. Simülasyon maketinde normal doğum yönetimine ilişkin performansın hakkında neler hissettiniz?

5. Simülasyon eğitimi yoluyla değişen fikirleriniz var mı?

\section{Verilerin değerlendirilmesi}

Yapılan görüşmeler ses kaydına alınarak, daha sonra deşifre edilmiştir. Veriler toplandıktan sonra analizinde, araştırma kapsamındaki tema ve kategorileri oluşturmak amacı ile tümevarımcı niteliksel içerik analizi kullanılmıştır (5). Bu analiz yöntemi ile hem katılımcıların ifadelerinden elde edilen görünen içerik, hem de araştırmacının yorumlaması ile sözel ifadelerin altında yatan gizli içerik analizi yapılmıştır. Araştırmacılar tarafından öncelikle bireysel derinlemesine yapılan görüşmelerin ses kayıtları ve alınan notlar, yazılı metne dönüştürülmüştür. Metinler literatürde belirtildiği gibi yüksek sesle okunarak, konu ile ilişkili olduğu düşünülen ifadeler renkli kalemle işaretlenmiştir ve bu görüşme metinleri birden çok kez okunmuştur.
Görüşme metni içeriğine "açık kodlama" (benzer anlam taşıyan ifadelerin belirlenmesi) ve belirlenen ifadelerin isimlendirilmesi ile "kodlama" yapılmıştır. İsimlendirilen kodlar benzerlikleri ve farklılıkları açısından kategori ve alt kategorilere ayrılmıştır. Kategorilerin anlamlarını birbirine bağlayarak temalar oluşturulmuştur. Metinlerde ortak temalar belirlenerek araştırmacı tarafından kodlanmıştır.

\section{Bulgular}

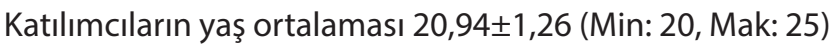
ve hepsi bekardır. Ortalama görüşme süresi 16 dk 36 sn sürmüştür (Min: 11:44 Mak: 22:15). Yapılan görüşmelerden tematik içerik analizine dayanarak, öğrencilerin deneyimleri üç kategoride kümelenmiştir: Simülasyon öncesi, Simülasyon ve Simülasyon Çekinceleri. Bu kategorilerden çeşitli temalar ortaya çıkmıştır ve elde edilen temalar Şekil 1 'de verilmiştir.

\section{Simülasyon öncesi}

Yapısal

Kalabalık ortam: Öğrencilerin uygulama eğitimi aldıkları doğum kliniklerinde asistan hekimlerin, ebelik ve hemşirelik öğrencilerinin sayıca fazla olması, öğrencilerin gebelerde uygulama fırsatlarının azalmasına neden olmaktadır. Bir öğrenci "Hastanede yapabildiğim tek şey tansiyon ölçmekti. Doğumhane, çok kalabalık, doktorlar, ebeler, öğrenciler.... Bir keresinde bir doğumda hepimiz toplanmıştık ve odada 21 kişi olduğumuzu saydım... biz, tıp öğrencileri.... doğumda... çok korkunç bir durum bence.... kalabalık..." (DE), cümlesiyle ortamdan duyduğu rahatsızlığı dile getirmektedir. Bir diğer öğrenci ise; "Asistan hekimlerden bize sıra gelmiyor. İleyemiyorduk bile!. . . hastanede hiç yaklaşamamıştım doğuma, ... doğumları sadece izleyerek ebe olabilecek miydim?. .." (YB) şeklinde kaygısını dile getirmiştir.

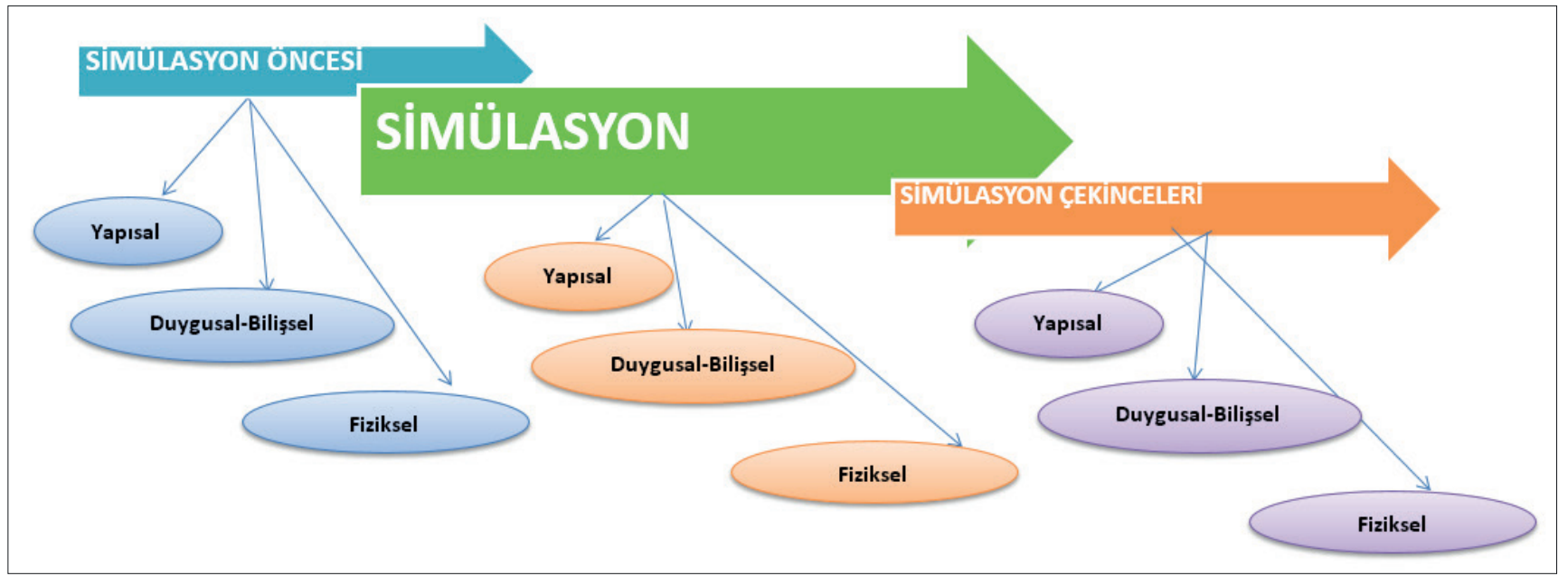

Şekil 1. Ebelik öğrencilerinin doğum simülasyon eğitimi deneyimleri 
Doğumhane ortamından farklı kliniklerde uygulama yapma, farklı işler yapma: Öğrencilerin diğer jinekoloji ünitelerinde görevlendirildikleri, doğumhanede kalabilenlerinse doğumu sadece izleyebildikleri belirlenmiştir. Bir öğrenci "Ben onkolojide çalıştım mesela geçen dönem, infertilite de çalışım... Ben ebe olacağım, nerede ebe olacaktım? poliklinikte smear kaplarının kapaklarını açıp kapatıyordum!. . en fazla arada kan alıyordum!..." (HR) ifadesiyle bu durumdan rahatsızlığını belirtirmişlerdir. Başka bir öğrenci ise "Spanç katlıyordum klinikte... Doğumları sadece uzaktan izliyordum, hele hızlı gelişen gerçek doğumlarda, öğrenmem zor$d u . "$ (ÖK) ifadesiyle deneyimi paylaşmıştır.

\section{Duygusal-Bilişsel}

Hastanede görevli hekim ve ebeler ile kötü iletişim ve mobbing yaşama: Öğrenciler, diğer sağlık çalışanları ile sağlıklı iletişim kuramadıkları ve hatta mobbinge maruz kaldıkları belirlenmiştir. Bir öğrenci, "Sabah gidiyoruz mesela bize günaydın-bile demiyorlar..." (ÖR) olarak deneyimini paylaşırken bir diğer öğrenci "Orada çalışanların bize karşı davranışları çok kötüydü... bize kötü davranmalarına rağmen, orada bir şeyler öğrenmeye çalışıyordum..." (MA) ifadesini kullanmıştır. Bir öğrenci "klinik uygulamalar süresince bize "sakın hiçbir şeye dokunmayın... başımızda kalabalık etmeyin... diyorlardı, sürekli azarlandığımız zamanlar bile oldu..." (EB) ifadesiyle deneyimini paylaşırken bir diğer öğrenci "Klinikte itilip kakıldığımı hissetmiştim, birde üniversite öğrencisiyim!. . . kendime güvenim gitmişti..." (DG) şeklinde duygularını ifade etmiştir.

Korku ve tedirginlik: Ebelik öğrencilerinin klinik ortamda, anne ve bebeğe zarar verme korkusunu yoğun bir şekilde hissettikleri görülmüştür. Bu bağlamda bir öğrenci "kendimi cellat gibi hissediyordum hastanede, ilaç hazırlarken..., Her an zarar verebilecek potansiyelde hissediyordum kendimi, o yüzden de hiç olmadığım kadar özgüvensiz ve eksik hissediyordum...." (AE) ifadesiyle yaşadığı korku duygusunu paylaşırken bir diğer öğrenci“... korkuyordum, annenin canını acıtırsam, ya bebeğe bir şey olursa... benim o anda elim ayağım tir tir titriyordu..." (AG) şeklinde yaşadığı korku duygusunu ifade etmiştir.

Yetersizlik hissi: Bu konuda bir öğrenci "Tuşe yaptığımda hiçbir şey anlayamadım, gebeyi ajite etmemek içinde çok uzun da tutamadım, ne yapacağımı bilemediğimden... Mesleki anlamda çok yetersiz hissediyordum kendimi......." (YB) ifadesiyle deneyimini paylaşmıştır.

Hastane ortamından travmatize olma: Ebelerin gebelere kötü davranışlarına şahit oldukları ve öğrencilerin bu durumdan olumsuz etkilendikleri belirlenmiştir. Bir öğrenci "Gittiğim hastanede doğum masasında gebelere bağırıyorlardı..., benim ağlayasım geliyordu..., çok korktum, ebe olma isteğim kalmadı" (MA) şeklinde deneyimlerini ifade etmiştir.

\section{Fiziksel}

Öğrencilerin doğum yönetimini öğrenememenin verdiği eksiklik hissi ve yakın gelecekte doğum yönetimini bilmeden mezun olma kaygısının fiziksel belirtilerle de kendini gösterdiği belirlenmiştir. Bir öğrenci "Çok endişeliydim, henüz bir gebeye dokunamadığım, doğum yaptırmadım için hep böyle uykularım kaçıyordu." (KE) şeklinde yaşadığı rahatsızlığın kendisini fiziksel olarak da nasıl etkilediğini dile getirmiştir.

\section{Simülasyon}

Yapisal

Tekrar edebilme şansının olması: Simülatörün canlı olmaması sayesinde her anlaşılamayan durumun tekrar edebilme şansının olmasının öğrencilerin eğitimini desteklediği görülmüştür. Bu konuda bir öğrenci “Makette istediğim kadar ve istediğim süre tuşe yapabildim... Gerçek gebede bunu yapmam mümkün değildi." (DE) olarak tanımlarken bir diğer öğrenci "Tekrar tekrar tuşe yapmak hem kadın için, hem bizim için çok irrite edici olacağından simülatör öğreticiydi" (BE) diyerek simülatörde öğrenmenin memnuniyetini dile getirmiştir. Bir başka öğrenci ise "Simülatör bir canlı olsay$d_{\imath}$... bu kadar yararlanamazdık diye düşünüyorum..., gerçeğinde kim bilir kaç gebede öğrenebilirdik...." (RM) simülatör eğitiminin deneyim açısından ayrıca zaman kazandırdığını belirtmektedir.

Adım adım öğrenme: Doğumu adım adım öğrenme konusunda bir öğrenci "Bir insana kıyasla yavaş olduğu için doğumu adım adım kaçırmadan görmek, daha iyi öğrenmemi sağladı..." (DG) derken, başka bir öğrenci ise "simülasyonda, doğumun tüm aşamalarında ne olacağını yavaş yavaş adım adım görebilmek çok iyiydi, hastanede ne olduğunu bile anlayamadan her şey olup bitiveriyordu..." (KS) şeklinde deneyimini paylaşmıştır.

Güvenli uygulama ortamı: Simülasyon eğitiminin başında bir öğrenci "Yanlış yaparsam simülatör en çok öter diye düşündüm. Çünkü şu an zarar verebileceğim gerçek bir bebek ya da anne yok ve her müdahaleyi deneyerek öğrendim..." (DE) ifadesini kullanırken bir diğer öğrenci "Hastanede hep bir gebenin telaşı oluyordu, simülasyon güvenli bir öğrenme ortamı sunmasından dolayı güzeldi..." (AN) şeklinde deneyimini paylaşmıştır 


\section{Duygusal-Bilişsel}

Simülasyon eğitiminde eğitimcinin birebir desteğini hissetme: Simülasyon eğitiminde öğretim üyeleri ile birlikte uygulama yapma fırsatı bulmalarının, öğrenciler için oldukça rahatlatıcı olduğu belirlenmiştir. Bir öğrenci "Hocayla birlikte kendimi çok ayrıcalıkı hissettim!. . . Evet! . . benim korkumu görerek, korkumu yenmemi sağladı. Yanlış yapacak bile olsam bana dur diyebilecek, yanlışıma müdahale edebilecek biri vardı" (ÖK).

Doğum yönetimini öğrenme: Öğrencilerle yapılan görüşmelerde doğum yönetimini öğrenme konusunda teorik ve pratiği birleştirme ihtiyacının temel mesleki ihtiyaç olduğu belirlenmiştir. Bu bağlamda bir öğrenci "Teorikte anlamıştım ama uygulamaya geçiremediğimiz için hep bir şeyler havadaydı. Mesela bebeğin posizyonunu doğum şeklini filan biliyordum teorikte ama, kafamda canlandıramıyordum. Uygulamaya geçirdiğimde, gerçekten o kadar her şey oturuyor ki yerli yerine., yapboz parçaları gibi...çok etkili oldu bende." (RM). Vajinal muayene öğrenci ebelerin öğrenmek zorunda olduğu en karmaşık becerilerden birisidir. Bu konuda bir öğrenci "Doğumu yönetimini simülasyon eğitimi ile öğrendim. Doğum görerek ve hissederek öğrenebileceğimiz şeylermiş. Maalesef görmeden, dokunmadan, hissetmeden öğrenilecek bir şey değilmiş doğum." (DG) ifadesiyle deneyimini paylaşmıştır. Bir diğer öğrenci "hastane ortamında tuşe bana, kadına çok rahatsızık veren bir şeymiş gibi geliyordu. Ama şu an doğumun seyri için gerçekten gerekli olduğunu anladım..." (ASN) ifadesini kullanmıştır.

Korkusunun azalması ve özgüvenlerinin artması: Bu bağlamda bir öğrenci "Ben çok uzaktım ebeliğe, doğuma!. . . Şu an gerçekten korkum yıkıldı ve ebe olabileceğime, doğum yaptırabileceğime olan inancım, ben bunu yapabilirim inancım geldi..." (DÖ) bir diğer öğrenci "Neler yapmam gerektiğini öğrendiğim için, benim korkumda azaldı, özgüvenim arttı, doğum yaptırabileceğime inanıyorum!. . ." (AN), başka bir öğrenci de "Önceden zarar vermekten çok korkuyordum!... Bu korkuyu sümülasyonla yendiğimi düşünüyorum." (DÖ) ifadesiyle duygusunu paylaşmıştır.

Ebe ve doğum algısının değişmesi, mesleğe aidiyet hissi: $\mathrm{Bu}$ bağlamda bir öğrenci "Öncesinde benim ebeliğe bakışım "Iyyy, ne kadar pis bir meslek..." di. Yani biraz da böyle iğreniyordum da..., ama şimdi daha profesyonel bakabiliyorum" $(A F)$ ifadesini kullanırken bir diğer öğrenci "Simülasyon eğitimi öncesinde ebeliğin "geri kalmış bir meslek" olduğunu düşünüyordum, Hani biri bana sorduğunda bile ebelik okuyorum ve ebe olacağım demeye utanıyordum açıkçası, ama şimdi... özgüvenim bayağı yükseldi. Çok güzelmiş, ebelik..."
(GH) şeklinde paylaşımda bulunmuşlardır. Simülasyon eğitimi öncesinde ebelik algısının olumsuz olması nedeniyle doğumdan uzak bir kurumda çalışmayı planlayan öğrenci ise simülasyon eğitimiyle bu fikrinin değiştiğini belirtmiştir. Bu bağlamda öğrenci "Simülasyon eğitiminden önce, mezun olunca sağlık ocağı gibi yerlerde çalışabilirdim belki... diye düşünüyordum, ama şu an aktif ebelik yapabileceğimi düşünüyorum..." (MA), diğer bir öğrenci de "Kendimi öğrenciden çok "ebe gibi hissediyorum", iyi hissettiriyor!. . . simülasyon eğitimi bu güveni aşılamış oldu bana. Bundan öncesinde hep yarım kalmıştı ebe kimliğimiz...." (DG) şeklinde deneyimlerini paylaşmıştır. Öğrencilerin hepsi simülasyon eğitimi öncesinde ebe rolünü tam olarak hissedemediklerini belirtmişlerdir.

\section{Fiziksel}

Simülasyon eğitiminde öğrencilerin el becerilerinin geliştiği ve fiziksel olarak rahatladıkları görülmüştür. Bu bağlamda bir öğrenci "Bir ebenin parmakları gözleridir diye söyleniyor... elimle görmem gerekiyormuş. Aslında anlaşılması çok kolaymış. -Bunu yapabilirim-dedim!. . . Simülasyon eğitimi çok rahatlattı beni... (ÖK)" şeklinde deneyimini paylaşırken bir diğer öğrenci "El becerim gelişti. Bebeğin geliş pozisyonunu hissetmede daha hassaslaşabildim" (DE) şeklinde deneyimini paylaşmıştır. Ayrıca simülasyon eğitimi öncesinde uygulama fırsatının az olması ve nasıl ebe olacağı konusunda yüksek düzeyde kaygısından dolayı uykusuzluk yaşadığını belirten bir diğer öğrenci de simülasyon eğitiminin faydasını "uyku kalitemi artırdı, artık rahat uyuyabiliyorum" (KE) olarak değerlendirmiştir.

\section{Simülasyonun çekinceleri}

Yapısal

Simülatöre çeşitli vaka olmamasının simülasyon eğitiminin önemli çekincelerinden biri olduğu görülmüştür. Bu konuda bir öğrenci: "Hastanede daha çok vakayı bir anda görebiliyoruz... Hani makette de bir noktadan sonra tekrarlamaya başlıyor, aynı şeyler olduğunu görüyoruz. Çünkü doğum o kadar" (MA) ifadesiyle bu konudaki deneyimini belirtmiştir. Ayrıca simülasyon eğitimi süresince aynı bebek maketinin kullanılması, ıslak ve sıcak olmaması, tepkisiz olması ve maketle iletişim kurulmaması nedeniyle öğrenciler zorluk yaşamışlardır. Bir öğrenci bu konuda "Hani biraz şüphelerim var.... Gerçekle uyumlu mu? Simülatörde bebeğin kafası saçlı değil, simülatörde direk elime geliyor mesela sagital süturu filan, hastanede hissetmek daha zor olabilir. Maket sadece yatıyor, bir tepki gelmeyince, duvara konuşmuş gibi hissettim kendimi..." (GH) ifadesini kullanarak, simülatörün gerçeğe uygunluğu konusunda çekincelerini dile getirmiştir. 


\section{Duygusal-Bilişsel}

Simülatörün laboratuvar ortamında olması ve klinik ortamdan uzak olması nedeniyle de gerçeğe uygunluğu konusunda çekincelere açmıştır. Bununla ilgili bir öğrenci "Daha yavaş ilerliyor, panik ortamı olmuyor, hastanede birisi oradan bi şey yapıyor, diğeri öbür taraftan başka bir şey... burada gayet sakindik... Hastane ortamında bu biraz zor." (ÖR), bir diğer öğrenci "Maket üzerinde çok rahattım. Gerçek gebe üstünde belki biraz panik olabilirim, doğumhane deki heyecan ve paniği yaşamadığımız için, Doğumhanelerde hep bir telaş hep bir kargaşa var...." (DG), başka bir öğrenci de "sadece kadının karşımızda canlı olmadığını bildiğimiz için rahat hissettim kendimi, karşımızda canlı bir insan olduğunda biraz daha korkabilir anda ne yapacağımızı bilemeyebilirim." (KS) ifadeleriyle maketle ilgili çekincelerini dile getirmişlerdir.

\section{Fiziksel}

Fiziksel olarak simülatörün çok iyi ıkınması ve maketin yorulmamasının simülatörün gerçekliği konusunda çekincelerden birisidir. Bir öğrenci "Maket çok iyi ıkınıyor. Maket yorulmuyor. Ama normal kadında bu süreç biraz daha farklı, onu yönetmek hani biraz daha zor olabilir belki..." (MA) ifadesiyle bu konudaki çekincesini dile getirmiştir.

\section{Tartışma}

ICM'nin, eğitim, yeterlilik ve eğitim standartlarını yayınlamasına rağmen (6) ebelik eğitiminde klinik ortamda öğrencilere sağlıklı öğrenme ortamları ülkemiz de dâhil olmak üzere henüz istendik şartlarda sağlanmamaktadır. Klinik eğitim süresince kalabalık ortam, öğrencilerin uygulama şansının ciddi şekilde azalmasına yol açtığından öğrencilerin çoğunluğu uygulama yapmak için fırsat ya da uygun ortam bulamamaktadır. Bu çalışmaya benzer şekilde Bharj \& Embo (2018); doğum kliniklerinde, ebeliğin yanında farklı disiplinlerden gelen öğrenci sayısındaki artışın öğrenme kalitesini olumsuz etkilediği ve birçok ebelik öğrencisi tarafından büyük bir sorun olarak görüldüğü bildirmektedir (6). Bu çalışmada ebelik öğrencilerinin doğum klinikleri dışında görevlendirilmeleri yurt dışında örneklerine rastlanmayan bir uygulamadır. Bu durum öğrencinin sadece deneyim kazanmasını engellemekten öte, meslekten hızla soğumasına ve aidiyet duygusunun azalmasına yol açabilmektedir. Ayrıca doğum kliniğinde uygulama için gidebilen öğrenciler de, ülkemizde doğum kliniklerinin çok kalabalık olmasının yanında malpraktis davalarının çok fazla oranda yaşanması ve bu nedenle de bu kliniklerde görevli sağlık personelinin genel tutumunun "ekipten olmayana fazla güvenmeme ve hastaya dokundurtmama" üzerine yoğunlaşan anlayışın hâkim olmasından dolayı da geri planda kalabilmektedir.
Rees et al. (2018) yalnızca klinik gözlem ve klinisyenlerle birlikte bakım sunma değil, klinisyenlerden kısa bilgilendirme ve geribildirim almanın önemli olduğunu belirtmektedir (7). Klinikteki sağlık ekibinin, öğrencilere rehberlik etmek sorumluluğu bulunmasına rağmen bu çalışmada öğrencilerin sağlık ekibi tarafından mobbinge maruz kaldıkları belirlenmiştir. Bu çalışmaya benzer şekilde Malwela et al. (2016) yaptığı çalışmada profesyonel ebelerin öğrencilere yönelik olumsuz tutumları olduğunu ve öğretmekte gönülsüz olduklarını saptamıştır (8). Došler et al. (2014) ebelik öğrencilerinin klinik ortamda mobbing'e maruz kalma oranının \%82,3 gibi yüksek bir oranda olduğunu belirtmiştir (9).

Bu çalışmada öğrencilerin zarar verme korkusunu yoğun olarak hissettikleri ve öğrencilerin kendilerini yetersiz hissettikleri belirlenmiştir. Bu çalışma ile benzer şekilde diğer çalışmalarda da öğrencilerin başlıca; zarar verme, doğum sürecini yürütememe, ilk doğum yaptırma ve ceza alma korkusu yaşadıkları ve öğrencilerin kaygısını artırdığını belirlenmiştir (10-13).

Öğrencilerin klinikte travmatize oldukları önemli bir çalışma bulgumuzdur. Bu çalışmaya benzer şekilde, ebelik öğrencilerinin \%96'sı klinik uygulamaları sırasında kadınlara ciddi saygııızıkla karşılaştıklarını bildirilmiştir (14). Doğum kliniklerinde fiziksel ve sözlü istismarın sık görüldüğü, hatta insanlık dışı ve son derece saygısız tavırlarla kadınların karşılaştığı $(15,16)$, ebelik öğrencilerinin çalışma ortamlarında ciddi psikolojik sıkıntılar deneyimledikleri (17) ve ebelerin işle ilişkili psikolojik distres deneyimleme riskinin giderek arttığı bildirilmektedir (18). Ebelik öğrencilerin yaklaşık yarısının tükenmişlik duygularının yüksek olduğu (19), ebelerin çalışma ortamlarında işle ilişkili stres ve travmatik olaylardan sonra, kendilerinin de travma tepkisi verdikleri bildirilirken (20), bir diğer araştırmada ebelerin çalışma ortamında personel yetersizliği, kanıta dayalı uygulamalara zaman ayıramama nedeniyle anne ve bebeklerin güvenliği ve kendi iyilikleri hakkında kaygı duydukları ve kişilerarası ilişkilerde ciddi sorunlar yaşadıklarını bildirmektedir (21).

Ebelik öğrencilerinin tekrarlanan uygulama sayesinde, yaptıkları uygulamaları gözden geçirmeleri ve geri bildirimlerle güçlendirilmelerinin güvenlerini artırdığı (2), simülasyon eğitiminin uygulamayı tekrar edebilme fırsatının öğrencileri desteklediği bildirilmektedir (1). Simülasyon eğitiminin etkili bir araç olduğu belirtilirken (22) yapılan bir diğer çalışmada simülasyon eğitiminde öğrencilerin 76 kez tekrar ettikten sonra \%65'inin tam 
olarak doğru ölçüm yapabildiği bildirilmektedir ve aynı çalışmada mezuniyetten önce öğrencilerin yeterlilik kazanmaları için uygulamaları en az 100 kez tekrarlamaları tavsiye edilmektedir (23). Literatürde belirtilen uygulamayı tekrar etmenin öğrenci memnuniyetini arttırması ve öğrenmeyi kolaylaştırmasının, bu çalışmayla benzer olduğu görülmüştür.

Son yıllarda doğum sürecinde vajinal muayene sayısının artmasının potansiyel riskleriyle ilgili literatürde gittikçe artan sayıda yayın görülmeye başladığından bu yana öğrencilerin klinik ortamda uygulama şansları azalmaktadır (13). Ayrıca gereksiz yere tekrarlanan vajinal muayenelerin kadın tarafında travmatik olarak algılanması nedeniyle (24) etik olarak da uygun değildir. Bu çalışmaya benzer şekilde simülasyon eğitiminin hem öğrenciler hem de hastalar için güvenli bir ortamda klinik becerilerini geliştirme fırsatı sunduğu belirtilmektedir $(1,3,8,25,26)$. Simülatör sayesinde ebelik öğrencilerinin vaginal muayeneyi en iyi şekilde öğrenmelerini sağlayabildiği bildirilmektedir (27). Ayrıca ebelik eğitiminde öğrencilerin yeterliliğine yönelik değerlendirmenin belirli bir sayıdan ziyade, öğrencinin beceriyi adım adım, yeterli ustalık kazanmasına dayandırılması gerektiğini belirtilmektedir (13). Simülasyon eğitiminde birebir öğretim üyesi tarafında rehberlik edilmesinin de, yanıtlanmayan hiçbir soru kalmaması kalmamasını ve öğretim üyesinin izin verici tutumunun güvenli bir çevre oluşturduğu bulgumuz literatürle uyumludur $(1,2)$.

Diğer çalışmalara $(1,2,3,28,29)$ benzer şekilde bu çalışmada da ebelik öğrencileri gözlem yapmaktansa uygulayarak daha çok şey öğrendiğini, yalnızca teorik bilgilerle doğum yönetimini öğrenmenin güç olduğunu ve simülasyon eğitimiyle teori ve pratiğin birleşmesi aracılığıyla

\section{Kaynaklar}

1. Lendahls L, Oscarsson MG. Midwifery students' experiences of simulation-and skills training. Nurse Educ Today 2017;50:12-6. [CrossRef]

2. Vermeulen J, Beeckman K, Turcksin R, Van Winkel L, Gucciardo L, Laubach $M$, et al. The experiences of last-year student midwives with High-Fidelity Perinatal Simulation training: A qualitative descriptive study. Women Birth 2017;30:253-61. [CrossRef]

3. Maskálová E, Urbanová E, Bašková M, Kvaltínyová E. Experience of lecturers with simulation training in midwifery education in Slovakia. Midwifery 2018;59:1-3. [CrossRef]

4. OECD Data, Caesarean sections. Health at a Glance, 2019. https:// data.oecd.org/healthcare/caesarean-sections.htm

5. Yıldırım A, Simsek H. Qualitative Research Methods 2008. Seçkin Publishing, Ankara.

6. Bharj KK, Embo M. Factors affecting quality of midwifery students learning in the workplace: Results of two ICM congress workshops. Midwifery 2018;30;62:116-8. [CrossRef] öğrendiklerini, öğrencilerin yeterliliğinin ve özgüveninin arttığı saptanmıştır. Bu çalışma sonucuyla benzer şekilde, ebelik öğrencilerinin hissettiği korkunun, öğrencilerin profesyonel rollerini benimsemelerini engellediği bildirilmektedir (10). Ayrıca simülasyon eğitimi yoluyla öğrencilerin "profesyonel kimliğini keşfetme" fırsatı kazandıkları ve ebe rolünün gelişimini desteklediği bulgumuz literatürle uyumludur $(22,30)$.

Simülasyon eğitiminde öğrencilerin el becerisinin artması bulgumuz literatürle uyumludur $(1,28,29)$. Bu çalışmada elde edilen diğer bir bulgu, ebelik öğrencilerinin simülasyon eğitimini olumlu ve değerli bir öğrenme yöntemi olarak değerlendirdikleri belirlenmiştir. Bununla birlikte, özellikle doğum simülatörleri kullanılırken simülasyon eğitimi bazı sınırlamalara sahiptir. Temel problemler arasında doğum simülatörlerinin kalitesi, en çok vurgulanan parçaların hızla bozulması, gerçekçilik eksikliği ve yüksek maliyet bulunmaktadır (3).

\section{Sonuç}

Simülasyon eğitimi ebelik öğrencilerinin öğrenmesinde etkilidir ve pek çok avantajı vardır. Simülasyon eğitimi sonrasından öğrencilerimizden gelen geri bildirimlerin çoğunlukla pozitif yöndedir. Simülasyon eğitimi ayrıca profesyonel ebe kimliğini alabilmelerinde destekleyici rol üstlenmektedir. Ebelik öğrencilerinin eğitiminde teknolojinin kullanımı oldukça önemlidir.

\section{Teşekkür}

Araştırmada kullanılan simülatör, Marmara Üniversitesi Bilimsel Araştırma Projeleri Koordinasyon Birimi (BAPKO) (Proje No: SAG-E-090517-0244, 2018) desteği ile alınmıştır.

7. Rees $C E$, Crampton $P$, Kent $F$, Brown $T$, Hood $K$, Leech $M$, et al. Understanding students' and clinicians' experiences of informal interprofessional workplace learning: an Australian qualitative study. BMJ Open 2018;17:8:e021238. [CrossRef]

8. Malwela T, Maputle SM, Lebese RT. Factors affecting integration of midwifery nursing science theory with clinical practice in Vhembe District, Limpopo Province as perceived by professional midwives. Afr J Prim Health Care Fam Med 2016;8:a997. [CrossRef]

9. Došler AJ, Skubic M, Mivšek AP. Perception of mobbing during the study: results of a national quantitative research among Slovenian midwifery students. Coll Antropol 2014;38:1009-15. https:// www.researchgate.net/publication/268873801_Perception_of_ mobbing_during_the_study_results_of_a_national_quantitative_ research_among_Slovenian_midwifery_students

10. Ahmadi G, Shahriari M, Kohan S, Keyvanara M. Fear, an unpleasant experience among undergraduate midwifery students: A qualitative study. Nurse Educ Pract 2018;29:110-5. [CrossRef]

11. Dahlen HG, Caplice S. What Do Midwives Fear? Women and Birth 2014;27:266-70. [CrossRef] 
12. Kosgeroglu N, Acat MB, Ayranci U, Ozabaci N, Erkal S. An investigation on nursing, midwifery and health care students' learning motivation in Turkey. Nurse Educ Pract 2009;9:331-9. [CrossRef]

13. Roosevelt L, Diebel M, Zielinski RE. Achieving competency in vaginal examinations: The challenge of balancing student learning needs with best practice in maternity care. Midwifery 2018;61:39-41. [CrossRef]

14. Moyer CA, Rominski S, Nakua EK, Dzomeku VM, Agyei-Baffour P, Lori $J R$. Exposure to disrespectful patient care during training: Data from midwifery students at 15 midwifery schools in Ghana. Midwifery 2016;41:39-44. [CrossRef]

15. Burrowes S, Holcombe SJ, Jara D, Carter D, Smith K. Midwives' and patients' perspectives on disrespect and abuse during labor and delivery care in Ethiopia: a qualitative study. BMC Pregnancy Childbirth 2017;22;17:263. [CrossRef]

16. Bradley S, McCourt C, Rayment J, Parmar D. Disrespectful intrapartum care during facility-based delivery in sub-Saharan Africa: A qualitative systematic review and thematic synthesis of women's perceptions and experiences. Soc Sci Med 2016;169:15770. [CrossRef]

17. Pezaro S, Clyne W, Fulton EA. A systematic mixed-methods review of interventions, outcomes and experiences for midwives and student midwives in work-related psychological distress. Midwifery 2017;50:163-73. [CrossRef]

18. Coldridge L, Davies S."Am I too emotional for this job?"An exploration of student midwives' experiences of coping with traumatic events in the labour ward. Midwifery 2017;45:1-6. [CrossRef]

19. Beaumont E, Durkin M, Hollins Martin CJ, Carson J. Compassion for others, self-compassion, quality of life and mental well-being measures and their association with compassion fatigue and burnout in student midwives: A quantitative survey. Midwifery 2016;34:239-44. [CrossRef]

20. Sheen $K$, Slade $P$, Spiby $H$. An integrative review of the impact of indirect trauma exposure in health professionals and potential issues of salience for midwives. J Adv Nurs 2014;70:729-43. [CrossRef]
21. Mander R. Coded rhetoric: the reality of midwifery practice. $\mathrm{Br} \mathrm{J}$ Midwifery 2016;24:344-52. [CrossRef]

22. Song I, Jeong HC. Nursing students' experiences of simulation-based education on hypoglycemia. Int J Biosci Biotechnol 2015;7:147-54. [CrossRef]

23. Nitsche JF, Shumard KM, Fino NF, Denney JM, Quinn KH, Bailey JC, et al. Effectiveness of labor cervical examination simulation in medical student education. Obstet Gynecol 2015;126:13-20. [CrossRef]

24. Güneş G, Karaçam Z. The feeling of discomfort during vaginal examination, history of abuse and sexual abuse and post-traumatic stress disorder in women. J Clin Nurs 2017;26:2362-71. [CrossRef]

25. Arias T, Coxon K. An experiential model of education introduced to improve the confidence of student midwives in undertaking second stage management of the perineum (SSMP). Midwifery 2018;59:144-8. [CrossRef]

26. Ann Kirkham L. Exploring the use of high-fidelity simulation training to enhance clinical skills. Nurs Stand 2018;32:44-53. [CrossRef]

27. Granheim BM, Shaw JM, Mansah M. The use of interprofessional learning and simulation in undergraduate nursing programs to address interprofessional communication and collaboration: An integrative review of the literature. Nurse Educ Today 2018;62:11827. [CrossRef]

28. Catling C, Hogan R, Fox D, Cummins A, Kelly M, Sheehan A. Simulation workshops with first year midwifery students. Nurse Educ Pract 2016;17:109-15. [CrossRef]

29. Sundler AJ, Pettersson A, Berglund M. Undergraduate nursing students' experiences when examining nursing skills in clinical simulation laboratories with high-fidelity patient simulators: a phenomenological research study. Nurse Educ Today 2015;35:125761. [CrossRef]

30. Ruyak SL, Migliaccio L, Levi A, Patel S. Role development in midwifery education: A place for simulation. Midwifery 2018;59:141-3. [CrossRef] 